\title{
Physico-chemical quality and sensory evaluation of pummelo fruit as influenced by potassium fertilization
}

Alminda M. Fernandez ${ }^{1 *}$ and Constancio C. De Guzman ${ }^{2}$

This study aimed to determine the influence of potassium (K) fertilization on the physico-chemical and sensory qualities of 'Magallanes' pummelo [Citrus maxima (Burm. Ex Rumph.) Merr.] fruit. The field experiment was conducted for 12 months at South Davao Corporation (SODACO) farm in Davao City. Five treatments with increasing $\mathrm{K}$ levels were applied per tree: control, no K, $150 \mathrm{~g} \mathrm{~K}$ basal, $225 \mathrm{~g} \mathrm{~K}$ basal, and $225 \mathrm{~g} \mathrm{~K}$ basal + foliar application. The fruit physicochemical qualities and sensory attributes were analyzed the following harvest. Data were analyzed using analysis of variance and honest significance difference tests.

Application of $225 \mathrm{~g} \mathrm{~K}$ rates positively influenced the fruit quality but not the sensory attributes of pummelo. Fruit pulp diameter increased by $36 \%$ while peel thickness decreased by $29-75 \%$. An increase of $39 \%$ juice weight per fruit was obtained in $150 \mathrm{~g} \mathrm{~K}$. The yield of juice per tree increased up to 11 times with $225 \mathrm{~g}$ $\mathrm{K}$ level. The $225 \mathrm{~g} \mathrm{~K}$ rates also increased juice $\mathrm{pH}$ by $8-12 \%$, titrable acidity by 9 times, and total soluble solids per tree by 6 times than no application. The application of $225 \mathrm{~g} \mathrm{~K}$ basal + foliar resulted to higher fruit weight, TA, and TSS in pummelo fruit. The results of the study indicated the important role of $\mathrm{K}$ in improving the fruit physico-chemical qualities in 'Magallanes' pummelo.

Keywords: Fruit quality, Physico-chemical properties, sensory, pummelo, potassium

\section{INTRODUCTION}

Pummelo (C. maxima [Burm. Ex Rumph.] Merr.; C. grandis Osbeck; C. decumana L.), locally known as suha or lukban has the largest fruit among all citrus species, growing as large as $30 \mathrm{~cm}$ in diameter and weighing as much as $10 \mathrm{~kg}$ per fruit. The

${ }^{1}$ University of the South Pacific, Alafua, Apia, Samoa

${ }^{2}$ University of the Philippines, Los Baños, Laguna, Philippines

*Corresponding Author. Address: University of the South Pacific, Alafua, Apia, Samoa; Email: alminda fernandez5@gmail.com 
distant markets and resists pests and diseases. For trees over ten years old, the yield of 20t ha- ${ }^{-1}$ is considered economically beneficial (Magat and Mantiquilla 2005).

At present, there is much interest in citrus fruits because they are one of the major sources of antioxidants called flavonoids in the human diet. These antioxidative phytochemicals or functional foods are widely recognized for their role in scavenging free radicals, which are involved in the etiology of many chronic diseases and increased survival rates of elderly. The distinct color of fruits such as in citrus, is especially considered a quality trait that correlates with the fruits' nutritional values, and health benefits.

Pummelo is one of the most popular species of the Citrus family which is an excellent source of antioxidant flavonoids. Fresh red pummelo juice is an excellent source of antioxidant compounds which exhibited great efficiency in scavenging different forms of free radicals including 2, 2-diphenyl-1-picrylhydrazyl (DPPH), superoxide anion, and hydrogen peroxide radicals (Tsai et al 2007).

The potential biological activities of citrus flavonoids as an antioxidant, anticancer, antiviral, anti-inflammatory, and their effects on capillarity, in lowering cholesterol level, and in inhibiting human platelet aggregation are well documented (Benavente-Garcia et al 1997, Guthrie et al 2000, Middleton and Kandaswami 1994). One or more of the citrus flavonoids may be responsible for the above cited possible beneficial effects, and chemists are now developing new methods for making anticancer flavanones.

Furthermore, pummelo is a very nutritious fruit and is an excellent source of vitamin $\mathrm{C}$. Each serving of pummelo provides about twice the daily recommended amount of vitamin $C$ (Smith 2009). It also contains vitamins $A, B_{1}, B_{2}, B_{6}$ and $B_{12}$, protein, $\mathrm{Ca}$, fiber, folate, $\mathrm{K}$, and $\mathrm{Fe}$. Therefore, functional foods, such as pummelos, are a potent dietary option for preventing, diseases such as cancer, heart disease, hypertension, cholesterol, diabetes, asthma, common colds, inflammation, and diverticular diseases.

Pummelo peel also contains essential oils which have applications in the food and flavor industries. The oils are used for the synthesis of fine chemicals and new fragrances for the cosmetics industry, and for medicinal purposes in Oriental cultures (Njoroge et al 2005, Lis-Balchin and Hart 1999, Reische et al 1998).

As a health food with industrial use, there is a big demand for pummelo in both domestic and export market considering that Malaysia and Thailand are actively selling pummelo to Singapore, Hongkong, Japan, and other countries (The National RDE Network For Fruit Crops 2002). However, production of pummelo is limited by problems like instability of fruit quality, nutritional disorders, and some pest and disease infections. Based on the Philippine Statistics Authority (2014), the area devoted to pummelo production in the Philippines, historically (2004-2013) has decreased from 5,211 to 5,164 has. Moreover, the production volume decreased from $35,488 m t$ to $29,940 \mathrm{mt}$ from 2004-2013.

Hence, there is a need to assess and improve the fruit quality and sensory attributes of pummelo to cater to the increasing demands of health-conscious consumers for both local and export markets. To increase fruit quality and taste, it is important to provide an efficient fertilizer program.

Potassium (K) is a macronutrient in plants that has multiple enzymatic and catalytic functions used in many photosynthetic and metabolic processes in plants. Among the important elements in plant nutrition, $\mathrm{K}$ is the most abundant element 
found in fruits and the highest nutrient removed in the soil. Thus, $\mathrm{K}$ is considered a key element in fruit production and quality worldwide (Erner et al 2005).

Studies on different rates of $\mathrm{K}$ fertilizers have been shown to increase growth, yield, and quality of several plants such as orange, grapefruit, lemon, papaya, avocado, watermelon, plum, and peach. Experimental evidences have also been demonstrated to affect functional components such as Vitamin $\mathrm{C}$, carotenoid, $\mathrm{K}$ levels and isoflavone content of tomatoes, grapefruit, orange, grapes, strawberries, and soybean.

The potential effect of $\mathrm{K}$ on the physico-chemical qualities and sensory attributes of pummelo fruit has not been investigated yet; hence, this particular study was conducted.

\section{MATERIALS AND METHODS}

\section{Field Experiment}

A field experiment was conducted at South Davao Corporation (SODACO), Calinan, Davao City for the 12-month duration from March 2010-February 2011 to evaluate the effect of application of $\mathrm{K}$ on the physico-chemical quality and sensory attributes of 13-year-old 'Magallanes' pummelo tree. The experiment was carried out in Randomized Complete Block Design (RCBD) with five treatments replicated three times. There were three sample trees per replication per treatment for a total of 45 pummelo trees with a planting distance of $7 \mathrm{mx} 8 \mathrm{~m}$ in a rectangular planting system. Soil and leaf tissue analyses were done to determine the nutrient requirement of the trees based on the standard procedures of the Department of Agriculture-Bureau of Soils Laboratory, Davao City. Soil sample at $30 \mathrm{~cm}$ deep was air-dried, pulverized, and placed in bags for analysis. Samples of 4-6 month-old leaves from non-fruiting terminals in the mid-region of the tree were collected and placed in bags for analysis. Result of the soil and leaf tissue analysis before and after the experiment is shown in Table 1.

Table 1. Soil analysis before and after the conduct of the study from the Bureau of Soils, Department of Agriculture, Davao City.

\begin{tabular}{lccccccc}
\hline \multicolumn{1}{c}{ Treatments } & Class & $\mathrm{pH}$ & $\begin{array}{c}\mathrm{OM} \\
(\%)\end{array}$ & $\begin{array}{c}\mathrm{OC} \\
(\%)\end{array}$ & $\begin{array}{c}\mathrm{N} \\
(\%)\end{array}$ & $\begin{array}{c}\mathrm{P} \\
(\mathrm{ppm})\end{array}$ & $\begin{array}{c}\mathrm{K} \\
(\mathrm{ppm})\end{array}$ \\
\hline Initial & Clay & 5.1 & 2.82 & 1.64 & 1.4 & 27 & 228 \\
Control & Clay & 4.7 & 4.75 & 2.76 & 2.5 & 52 & 300 \\
no K & Clay & 5.2 & 2.86 & 1.66 & 1.7 & 13 & 295 \\
150g K basal & Clay & 5.4 & 3.54 & 2.06 & 2.3 & 8 & 388 \\
$225 \mathrm{~g} \mathrm{~K}$ basal & Clay & 5.5 & 3.32 & 1.93 & 1.7 & 27 & 355 \\
$225 \mathrm{~g} \mathrm{~K}$ basal + foliar & Clay & 6.0 & 3.47 & 2.02 & 2.1 & 16 & 325 \\
\hline
\end{tabular}


All treatments were applied with recommended rate of NP except for the control (no fertilization).

\begin{tabular}{|c|c|c|c|c|c|}
\hline Soil Analysis Legend & Very Low & Low & Medium & High & Very High \\
\hline $\mathrm{pH}$ & $<4.4$ & $4.4-5.5$ & $\begin{array}{l}6.1-6.6 \\
5.6-6.0\end{array}$ & $\begin{array}{l}7.3-7.8 \\
6.7-7.2\end{array}$ & $\begin{array}{c}>9.0 \\
8.5-9.0 \\
7.9-8.4\end{array}$ \\
\hline $\begin{array}{l}\text { Organic Matter (OM) } \\
\text { Walkey Black (\%) }\end{array}$ & $<3.44$ & $3.44-6.88$ & $6.88-17.20$ & $17.20-34.40$ & $>34.40$ \\
\hline Organic Carbon (\%) & $<2$ & $2-4$ & $4-10$ & $10-20$ & $>20$ \\
\hline \multirow{2}{*}{$\begin{array}{l}\text { Nitrogen (\%) } \\
\text { OM (Wilde's Method) }\end{array}$} & \multicolumn{2}{|l|}{ Low } & Medium & \multicolumn{2}{|c|}{ Adequate } \\
\hline & \multicolumn{2}{|l|}{$<1.5$} & \multicolumn{2}{|l|}{$1.6-3.0$} & $>3.0$ \\
\hline \multirow{2}{*}{ Olsen Phosphorus (ppm) } & Very Low & Low & Medium & High & Very High \\
\hline & $<10$ & $10-20$ & $20-30$ & $30-50$ & $>50$ \\
\hline \multirow{2}{*}{$\begin{array}{l}\text { Extractable Potassium } \\
\text { (ppm) }\end{array}$} & Very deficient & Deficient & \multicolumn{2}{|c|}{ Possibly deficient } & Adequate \\
\hline & $<250$ & $260-500$ & \multicolumn{2}{|c|}{$510-750$} & $>750$ \\
\hline
\end{tabular}

Five treatments with increasing $\mathrm{K}$ levels were applied per tree: control, no $\mathrm{K}$, $150 \mathrm{~g} \mathrm{~K}$ basal, $225 \mathrm{~g} \mathrm{~K}$ basal, and $225 \mathrm{~g} \mathrm{~K}$ basal + foliar application. The area was applied with basal and foliar fertilizers following the recommendations of soil and leaf tissue analysis as practiced by the farm. The different rates of fertilizers were applied in installments: at flushing or flower bud initiation and at 30 and 60 days after flowering (DAF). All treatments were applied with recommended rate of fertilizers except for the control (no fertilization) at the rate of $400 \mathrm{~g} \mathrm{~N}, 100 \mathrm{~g} \mathrm{P}$, and $150 \mathrm{~g} \mathrm{~K}$ per tree except for no K. Urea (46-0-0). Complete (14-14-14) fertilizer, Solophos (0-18-0) and Muriate of Potash (0-0-60) were the sources of NPK fertilizers. Fertilizers were applied basally at 1.5-meter radius around the canopy. $\mathrm{K}$ foliar fertilizers were prepared by mixing the required amount of $\mathrm{K}$ fertilizer in water at the rate of $10 \mathrm{~g} \mathrm{~L}^{-1}$ and applied at 30 and 60 days after fruit set (DAFS) on target fruits and leaves. Adjuvant concentrate containing Poly (oxy-1,2-ethanediyl), alpha(4-nonylphenyl)-omega-hydroxy, branched was also added to improve the performance of the $\mathrm{K}$ foliar fertilizer. The pummelo trees were maintained by irrigating, weeding, pruning, and applying pesticide and fungicide whenever necessary.

The pummelo fruits were harvested after 156 days from fruit set. Fruit samples were sent after harvest to the Analytical Chemistry Laboratory of the Department of Science and Technology (DOST), Davao City, Philippines for physico-chemical analysis.

Data were analyzed using analysis of variance (ANOVA) and means were compared using Honest Significant Difference Test (HSD). 


\section{Physico-Chemical Quality}

To evaluate the effect of different $\mathrm{K}$ treatments on fruit quality of 'Magallanes' pummelo, the peel thickness, juice content (fruit weight, juice weight and percent juice), physico-chemical properties such as $\mathrm{pH}$, total soluble solids (TSS), titratable acidity (TA), TSS:TA and sensory evaluation were taken after harvest. There were three fruit samples per replication per treatment. Fruits were sectioned equatorially, and peel thickness was measured at four points equatorially using a hand caliper. Fruit weight was taken by weighing fruit after harvest, and fruit juice was extracted by hand and weighed using electronic weighing scale. This was done on a fresh weight basis and percent juice was computed using the following formula:

$$
\text { \%juice }=\frac{\text { juice weight }}{\text { fruit weight }} \times 100
$$

The extracted juice was analyzed for its physico-chemical properties. Fruit juice was extracted by removing the fruit peel (flavedo and albedo) and blending the fruit juice sac and pulp for $3 \mathrm{~min}$. The blended fruit juice was collected in $1000 \mathrm{~mL}$ Erlenmeyer flask and filtered using cheese cloth. The juice $\mathrm{pH}$ was measured using $\mathrm{pH}$ meter. The juice samples were thawed in room temperature and mixed by turning the tightly closed bottle up and down 3 times. The $\mathrm{pH}$ meter was standardized using two buffer solutions nearest to expected $\mathrm{pH}$ of the test solution and $\mathrm{pH}$ calibration results were recorded. The glass electrode was dipped into the test solution and two readings were taken. The test results were reported to the nearest 0.01 (AOAC International 2005). The total titratable acidity was determined by titrating the sample with a standard base. Five $\mathrm{mL}$ of clear juice was titrated after adding $50 \mathrm{~mL}$ of distilled water. Two to three drops of phenolphthalein indicator were added with a standard base $(0.1 \mathrm{~N} \mathrm{NaOH})$ to a faint pink color. Sampling was done per treatment. The percent TA was then computed from the amount of $\mathrm{NaOH}$ consumed to reach the end point (AOAC International 2005). The following formulas were used:

$$
\begin{aligned}
\% \mathrm{TA} & =\frac{(\mathrm{T}-\mathrm{B}) \times \mathrm{N}_{\mathrm{NaOH}} \times \mathrm{AF}}{\mathrm{mL} \text { or g sample } \times \mathrm{DF}} \times 100 \\
\mathrm{~T} & =\text { Volume of } \mathrm{NaOH} \text { used to titrate the sample, } \mathrm{mL} \\
\mathrm{B} & =\text { Volume of } \mathrm{NaOH} \text { used to titrate the blank, } \mathrm{mL} \\
\mathrm{N}_{\text {NaoH }} & =\text { Normality of } \mathrm{NaOH} \text { used, meq } \mathrm{mL}^{-1} \\
\mathrm{AF} & =\text { Acid Factor, } \mathrm{g} \mathrm{meq} \\
\mathrm{DF} & =\text { Dilution Factor (mL aliquot } \mathrm{mL}^{-1} \text { of diluted sample) }
\end{aligned}
$$

The \% TSS was determined in 1-2 drops of the titrate using the hand-held brix refractometer and expressed as percent by weight of sucrose or degree Brix (AOAC International 2005). The following formulas were used:

$$
\begin{aligned}
\% \mathrm{TSS} & =\mathrm{S}_{1}-/+\mathrm{S}_{2} \times \frac{\mathrm{W}_{1}+\mathrm{W}_{2}}{\mathrm{~W}_{1}} \\
\mathrm{~S}_{1} & =\text { Refractometer Reading (\%) } \\
\mathrm{S}_{2} & =\text { Correction Factor } \\
\mathrm{W}_{1} & =\text { Weight of Sample } \\
\mathrm{W}_{2} & =\text { Weight of Diluent }
\end{aligned}
$$

TSS / TA ratio was computed by dividing the TSS by TA. 


\section{Sensory Evaluation}

The samples were properly labeled and general procedures for a sensory test were conducted. The samples were numbered randomly and the order of presentation was determined using random numbers. Thirty (30) panelists were chosen to evaluate the sensory attributes of pummelo fruits such as color, aroma, flavor, sourness, sweetness, and general acceptability.

The panelists were composed of 15-45-year-old persons who consist of students, teachers, and laborers. The judges were chosen based on their familiarity and expertise of the pummelo taste. Each judge was served with pummelo fruit samples and water with the score sheet. A 7-point hedonic rating scale which ranged from 1 (weak) to 7 (intense) was used to determine the acceptability of each sensory attribute. The samples were identified and scores were summarized in a master sheet.

\section{RESULTS AND DISCUSSION}

\section{Peel Thickness}

Peel thickness is an important parameter that determines quality of 'Magallanes' pummelo. Large fruits with thin rinds are desirable based on consumer preference. The internal structure of a ripe 'Magallanes' pummelo is shown in Figure 1 for reference. The treatments significantly affected fruit pulp diameter and peel thickness but not fruit diameter.

Higher K rates increased fruit pulp of pummelo. The application of $225 \mathrm{~g} \mathrm{~K}$ basal increased fruit pulp diameter by 36 percent compared with the control. The control treatment was just similar to $150 \mathrm{~g} \mathrm{~K}$ basal and no $\mathrm{K}$ treatments in terms of fruit pulp diameter of pummelo (Table 2 and Figure 2 ).

No K treatment and control produced significantly thicker peels which were 0.5$0.8 \mathrm{~cm}$ thicker than the treatments with $150 \mathrm{~g} \mathrm{~K}$ and $225 \mathrm{~g} \mathrm{~K}$ rates. The highest \% peel thickness was obtained in the control followed by no K treatment, which were 50 $75 \%$ and $29-50 \%$ thicker, respectively, compared with the other rates of $\mathrm{K}$.

Table 2. Peel thickness, fruit pulp diameter, and fruit diameter (cm) of 'Magallanes' pummelo as influenced by K fertilization

\begin{tabular}{lcccc}
\hline Treatments & $\begin{array}{c}\text { Fruit } \\
\text { Diameter } \\
(\mathrm{cm})^{\mathrm{ns}}\end{array}$ & $\begin{array}{c}\text { Fruit Pulp } \\
\text { Diameter } \\
(\mathrm{cm})\end{array}$ & $\begin{array}{c}\text { Peel } \\
\text { Thickness } \\
(\mathrm{cm})\end{array}$ & $\begin{array}{c}\text { \% Peel } \\
\text { Thickness }\end{array}$ \\
\hline Control & 11.2 & $8.8 \mathrm{~b}$ & $2.4 \mathrm{a}$ & $21 \mathrm{a}$ \\
no K & 12.9 & $10.6 \mathrm{ab}$ & $2.3 \mathrm{a}$ & $18 \mathrm{~b}$ \\
$150 \mathrm{~g} \mathrm{~K}$ basal & 13.4 & $11.6 \mathrm{ab}$ & $1.9 \mathrm{~b}$ & $14 \mathrm{c}$ \\
$225 \mathrm{~g} \mathrm{~K}$ basal & 12.6 & $12.0 \mathrm{a}$ & $1.6 \mathrm{~b}$ & $13 \mathrm{c}$ \\
$225 \mathrm{~g} \mathrm{~K}$ basal + foliar & 13.7 & $12.0 \mathrm{a}$ & $1.6 \mathrm{~b}$ & $12 \mathrm{c}$ \\
\hline
\end{tabular}

Values with a common letter in a column are not significantly different at 0.05 level using HSD. All treatments were applied with recommended rate of NP except for the control (no fertilization).

ns - no significant difference 


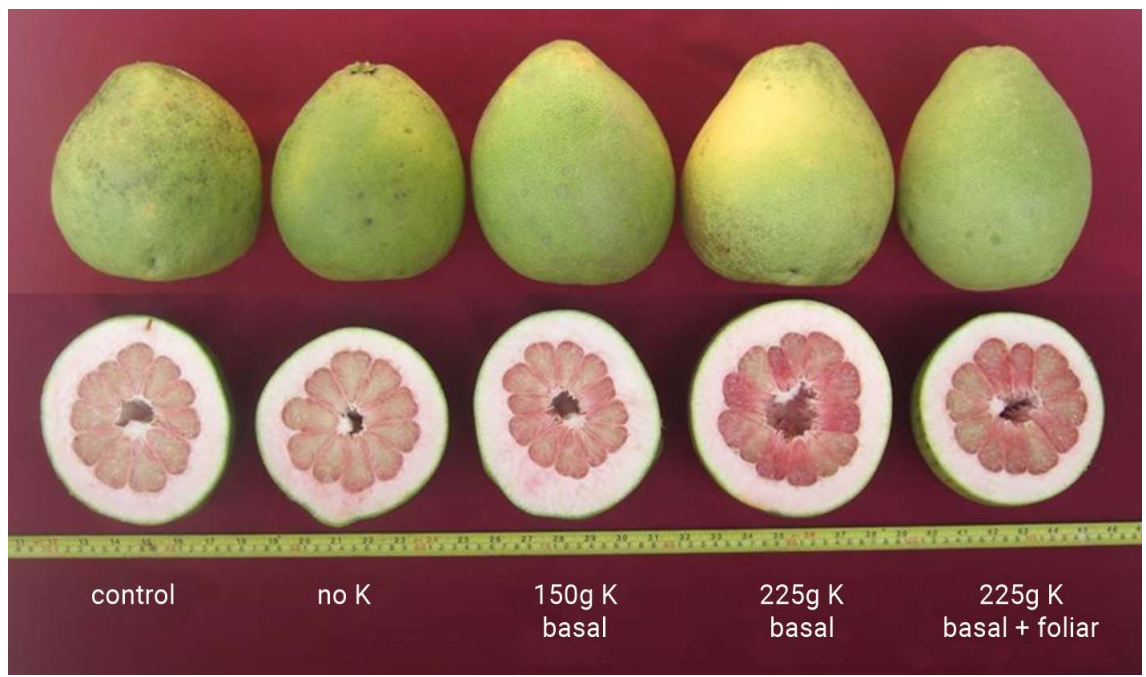

Figure 1. Peel thickness, fruit pulp diameter and fruit diameter $(\mathrm{cm})$ of 'Magallanes' pummelo as influenced by $\mathrm{K}$ fertilization. All treatments were applied with recommended rate of NP except for the control (no fertilization).

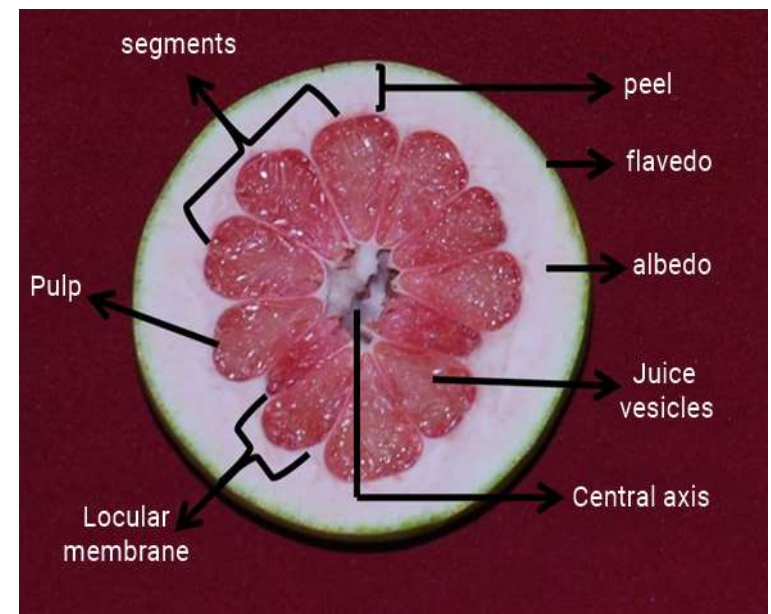

Figure 2. Internal structure of a ripe 'Magallanes' pummelo

The fruit pulp diameter of pummelo applied with $225 \mathrm{~g} \mathrm{~K}$ basal comprised of 88$95 \%$ of the fruit which was twice the average fruit pulp diameter (44\%) of 'Magallanes' pummelo (Estellana and Odtojan 1992). In a similar study, it was found out that $\mathrm{K}$ nutrition also significantly increased pulp thickness of papaya fruits (Kumar et al 2006).

The average peel thickness $(1.6-2.4 \mathrm{~cm})$ of the 'Magallanes' pummelo in this study, regardless of treatments applied was higher than the report of Estellana and Odtojan (1992) where average peel thickness of pummelo was only $1.5 \mathrm{~cm}$ thick. 
This study found out that $\mathrm{K}$ fertilization decreased peel thickness of 'Magallanes' pummelo by $29-75 \%$ compared with the control and no K treatments. This conforms to previous reports that $\mathrm{K}$ reduced peel thickness of 'Valencia' and 'Hamlin' oranges (Sites and Deszyck 1952, Alva et al 2002), and lemon (Embleton and Jones 1964). The peel thickness of 'Valencia' orange decreased from 6.04 to $5.77,6.72$ to 5.94 , and 4.13 to $3.88 \mathrm{~mm}$, in three experimental sites, respectively, for the trees which received $\mathrm{K}$ fertilization as compared to those which did not (Alva et al 2002).

In some cases, excessively high $\mathrm{K}$ levels result in large fruits with coarse, thick peel and poor color while too low $\mathrm{K}$ levels produced small fruits with thin rinds and good color (Erner et al 2005). Application of $\mathrm{K}$ at high rates $\left(>280 \mathrm{~kg} \mathrm{~K}_{2} \mathrm{O}\right.$ per ha) also increased fruit rind thickness of watermelon. This indicates that increasing $\mathrm{K}$ rate will reduce peel thickness, but application of $K$ rate at a certain level higher than the recommended rate will cause thicker rinds (Perkins-Veazie and Roberts 2002).

In this study, however, application of $150-225 \mathrm{~g} \mathrm{~K}$ effectively decreased peel thickness and increased fruit pulp diameter of 'Magallanes' pummelo. These observations indicate the importance of $\mathrm{K}$ in the fruit quality of 'Magallanes' pummelo.

\section{Juice Content}

The greater the edible portion of pummelo, which both producers and consumers prefer, the higher also the juice content. The effect in terms of fruit weight was similar among all treatments. Significant effects were observed, however, in juice weight (g), \% juice, and amount of juice (kg per tree).

The juice weight of pummelo applied with $225 \mathrm{~g} \mathrm{~K}$ basal + foliar increased by $39 \%$ compared to the control (Table 3 ). The juice weight from trees given $225 \mathrm{~g} \mathrm{~K}$ basal, $150 \mathrm{~g} \mathrm{~K}$ basal and no $\mathrm{K}$ were, however, not significantly different from that obtained from the control. Highest \% juice was obtained in $150 \mathrm{~g} \mathrm{~K}$ basal with $15 \%$ increase compared with the control and no K treatments. Higher $\mathrm{K}$ rates decreased percent juice by $6 \%$ and were not significantly different with the control.

The \% juice of pummelo applied with the $150 \mathrm{~g} \mathrm{~K}$ basal was $9 \%$ higher than the previous value (Estellena and Odtojan 1992) on juice content (28.9\%) of 'Magallanes' pummelo. In terms of amount of juice produced per tree, $225 \mathrm{~g} \mathrm{~K}$ basal + foliar generated the highest value, which was 11 times higher than the control and $38 \%$ higher than those applied with $225 \mathrm{~g} \mathrm{~K}$ basal. The juice yield for the no $\mathrm{K}$ treatment was not significantly different from the ones extracted for both the control and $150 \mathrm{~g} \mathrm{~K}$ basal treatments.

Results of this study agree to the previous findings (Alva et al 2002) that the juice content of 'Valencia' orange increased from 29.6 to $30.9 \%, 29.5$ to $34.3 \%$, and 41.6 to $44.2 \%$ in three experimental sites, respectively, for the trees which received $\mathrm{K}$ fertilization as compared to those which did not.

Increasing $\mathrm{K}$ rates to $225 \mathrm{~g} \mathrm{~K}$ basal + foliar application increased juice yield of 'Magallanes' pummelo by $2-8 \mathrm{~kg}$ per tree which indicates the importance of $\mathrm{K}$ fertilization in improving the volume of juice in pummelo. This is most likely related to the function of $\mathrm{K}$ in the translocation of assimilates and absorption of water and nutrients. $K$ increases fruit juice by acting as an osmoticum in plant cells to regulate water and solute uptake (Perkins-Veazie and Roberts 2002). K can substitute for $\mathrm{H}^{-}$ and the most important metabolites required for growth, storage, and transport of sucrose and amino compounds along the phloem (Van Bel and Van Erven 1979). 
Physico-chemical quality and sensory evaluation of pummelo

Table 3. Juice content of 'Magallanes' pummelo as influenced by $\mathrm{K}$ fertilization

\begin{tabular}{lcccc}
\hline Treatments & $\begin{array}{c}\text { Fruit Weight } \\
(\mathrm{g})\end{array}$ & $\begin{array}{c}\text { Nuice Weight } \\
(\mathrm{g})\end{array}$ & \% Juice & $\begin{array}{c}\text { Amount of } \\
\text { Juice } \\
(\mathrm{kg} \text { per tree) }\end{array}$ \\
\hline Control & 880.44 & $287.33 \mathrm{~b}$ & $32.98 \mathrm{~b}$ & $0.7 \mathrm{~d}$ \\
no K & 951.44 & $311.89 \mathrm{ab}$ & $33.01 \mathrm{~b}$ & $1.9 \mathrm{~cd}$ \\
$150 \mathrm{~g}$ K basal & 1023.00 & $387.22 \mathrm{ab}$ & $38.00 \mathrm{a}$ & $3.8 \mathrm{bc}$ \\
$225 \mathrm{~g}$ K basal & 848.78 & $300.89 \mathrm{ab}$ & $35.52 \mathrm{ab}$ & $5.9 \mathrm{~b}$ \\
$225 \mathrm{~g}$ K basal + foliar & 1118.56 & $399.33 \mathrm{a}$ & $35.71 \mathrm{ab}$ & $8.2 \mathrm{a}$ \\
\hline
\end{tabular}

Values with a common letter in a column are not significantly different at 0.05 level using HSD. All treatments were applied with recommended rate of NP except for the control (no fertilization).

ns - no significant difference

\section{Physico-Chemical Properties}

The $\mathrm{pH}$, titrable acidity (TA), total soluble solids (TSS) and TSS:TA of the fruit juice extracts are essential determining quality traits in pummelo. The sweetness and sourness which give a characteristic taste of the fruits are influenced by the fruit TSS which is attributed to the hydrolysis of insoluble starch into soluble sugar and the TA which can be accounted for by the increase in the activity of organic acid enzymes.

The various treatments significantly affected fruit juice $\mathrm{pH}, \mathrm{TA} /$ tree, TSS/tree and TSS:TA but not TA/fruit and TSS/fruit. Data showed that the effect between basal and foliar application of $\mathrm{K}$ in all parameters were the same (Table 4).

There was an $8-12 \%$ increase of $\mathrm{pH}$ in different rates of $\mathrm{K}$ and control compared with the no $\mathrm{K}$ treatment. The TA/tree of $225 \mathrm{~g} \mathrm{~K}$ rates was 9 times higher than the control. The control was not significantly different from no $\mathrm{K}$ and $150 \mathrm{~g} \mathrm{~K}$ rate. The TSS values per fruit were higher compared with the previous report of Estellena and Odtojan (1992) which was only $9 \%$.

Highest TSS/tree was also obtained in $225 \mathrm{~g} \mathrm{~K}$ application which increased by $100 \%$ up to 6 times compared with the $150 \mathrm{~g} \mathrm{~K}$, no K, and control. The TSS/tree of no $\mathrm{K}$ treatment was also similar to that of the control and $150 \mathrm{~g} \mathrm{~K}$ level. Increasing $\mathrm{K}$ rates did not increase TSS:TA per fruit, and highest TSS:TA was obtained from the control.

This study confirms to previous results that $\mathrm{K}$ fertilization increased juice acidity of 'Marsh' grapefruit (Calvert 1973); lemon (Embleton and Jones 1964, Koo 1963); 'Hamlin, 'Pineapple,' and 'Valencia' orange trees (Reese and Koo 1974, 1975); and strawberry (Choureitah and Bünemann 1972). Among the juice quality parameters, only acid content ( $\mathrm{TA}$ and $\mathrm{pH}$ ) was positively influenced by $\mathrm{K}$ application (Alva et al 2002). 
Table 4. Physico-chemical properties of 'Magallanes' pummelo as influenced by K fertilization

\begin{tabular}{lcccccc}
\hline \multirow{2}{*}{ Treatments } & \multicolumn{4}{c}{ TA $(\%)$} & \multicolumn{2}{c}{ TSS (\%) } \\
\cline { 2 - 6 } & pH & per fruit ns & per tree & per fruit ${ }^{\text {ns }}$ & per tree & TSS:TA \\
\hline Control & $4.54 \mathrm{a}$ & 0.39 & $1.04 \mathrm{~b}$ & 10.47 & $27.83 \mathrm{c}$ & $26.85 \mathrm{a}$ \\
no K & $4.07 \mathrm{~b}$ & 0.54 & $3.33 \mathrm{~b}$ & 10.04 & $64.23 \mathrm{bc}$ & $19.04 \mathrm{ab}$ \\
$150 \mathrm{~g} \mathrm{~K}$ basal & $4.39 \mathrm{a}$ & 0.54 & $5.36 \mathrm{ab}$ & 9.42 & $92.05 \mathrm{~b}$ & $17.49 \mathrm{~b}$ \\
$225 \mathrm{~g}$ K basal & $4.50 \mathrm{a}$ & 0.52 & $10.11 \mathrm{a}$ & 9.27 & $181.79 \mathrm{a}$ & $18.44 \mathrm{~b}$ \\
225g K basal + foliar & $4.55 \mathrm{a}$ & 0.48 & $10.51 \mathrm{a}$ & 9.70 & $201.61 \mathrm{a}$ & $20.73 \mathrm{ab}$ \\
\hline
\end{tabular}

Values with a common letter in a column are not significantly different at 0.05 level using HSD. All treatments were applied with recommended rate of NP except for the control (no fertilization).

ns - no significant difference

Results indicate that higher $\mathrm{K}$ level increased the $\mathrm{pH}, \mathrm{TA}$, and TSS per tree which shows the role of $\mathrm{K}$ in enhancing the juice attributes of 'Magallanes' pummelo. It is not known how the K level affects the accumulation or degradation of acids in citrus fruit (Erner et al 2005). In pummelo, K possibly activates enzymes that are involved in organic acid activity such as citric acid. Hobson and Davies (1971) suggested that in tomatoes, this may be due to a general increased synthesis of organic acids from up-regulation of the tricarboxylic acid pathway (TCA). Hale (1977) concluded that $\mathrm{K}$ increased malic acid concentration in grapes through increased membrane permeability and subsequent release of malic acid from the vacuole, rather than from increased acid synthesis.

On the other hand, $\mathrm{K}$ has never been shown to have any effect on sugar accumulation of citrus in field experiments (Erner et al 2005). However, results of the study showed that there was an increase in TSS content per tree in 'Magallanes' pummelo with $\mathrm{K}$ fertilizer application. In some studies, there was also an increase in TSS content with an increase in K supply in papaya (Kumar et al 2006), plum, and peach (Mimoun et al 2009). A large number of enzymes are dependent on or stimulated by $\mathrm{K}$ such as starch synthase and acid invertase activities (Fageria and Gheyi 1999). Thus, K may promote sugar translocation through the stimulation of starch synthase and acid invertase activities.

\section{Sensory Evaluation}

The sensory attributes (color, flavor, sweetness, and general acceptability) of pummelo fruit verified the results of the physico-chemical tests conducted. The different sensory attributes were significantly affected by the different treatments except in aroma and sourness.

The most intense color, desirable flavor, sweetest and most acceptable quality was obtained in the control having the highest TSS:TA (Table 5). Also, higher K rates had poor color compared with lower K rates. 
Physico-chemical quality and sensory evaluation of pummelo

Table 5. Mean sensory scores of 'Magallanes' pummelo attributes as influenced by K fertilization

\begin{tabular}{lcccccc}
\hline Treatments & Color & Flavor & Sweetness & Sourness $^{\text {ns }}$ & Aroma $^{\text {ns }}$ & $\begin{array}{c}\text { General } \\
\text { Acceptability }\end{array}$ \\
\hline Control & $5 \mathrm{a}$ & $5 \mathrm{a}$ & $5 \mathrm{a}$ & 3 & 5 & $6 \mathrm{a}$ \\
no K & $4 \mathrm{ab}$ & $4 \mathrm{bc}$ & $4 \mathrm{ab}$ & 4 & 4 & $4 \mathrm{bc}$ \\
$150 \mathrm{~g} \mathrm{~K}$ basal & $3 \mathrm{~b}$ & $3 \mathrm{c}$ & $3 \mathrm{~b}$ & 4 & 4 & $3 \mathrm{c}$ \\
$225 \mathrm{~g} \mathrm{~K}$ basal & $3 \mathrm{~b}$ & $4 \mathrm{ab}$ & $4 \mathrm{ab}$ & 4 & 4 & $4 \mathrm{~b}$ \\
$225 \mathrm{~g} \mathrm{~K}$ basal+foliar & $3 \mathrm{~b}$ & $4 \mathrm{abc}$ & $4 \mathrm{ab}$ & 4 & 3 & $4 \mathrm{bc}$
\end{tabular}

Values with a common letter in a column are not significantly different at 0.05 level using HSD. All treatments were applied with recommended rate of NP except for the control (no fertilization).

ns - no significant difference

Rating scale:

Color, Sweetness, Sourness and Aroma: 1-weak; 7- intense

Flavor: 1- undesirable; 7- desirable

General Acceptability: 1-unacceptable; 7-acceptable

Based on the result of the study, increasing the levels of $K$ fertilizer had no positive influence on the sensory attributes of 'Magallanes' pummelo juice extract. It was also observed that excessively high $\mathrm{K}$ levels resulted to poor color while too low K levels produced good color (Erner et al 2005).

This can be possibly explained by the result of competition among the developing fruits for a limited supply of metabolites (Guardiola 1997). Since the number of fruits obtained in the control was lower compared with higher $\mathrm{K}$ rates, there is lesser competition of assimilates in lower fruit load versus higher fruit load contributing to the increase in physico-chemical and sensory quality of the control over higher $\mathrm{K}$ rates. Nutrient utilization was evident which showed low $\mathrm{K}$ level in $225 \mathrm{~g} \mathrm{~K}$ basal + foliar treatment compared with the optimum level of $\mathrm{K}$ in the control based on the leaf tissue analysis after the conduct of the study.

\section{CONCLUSION}

Application of $225 \mathrm{~g} \mathrm{~K}$ rates enhanced the fruit physico-chemical qualities but not the sensory attributes of pummelo which are both of commercial importance. Fruit pulp diameter increased by $36 \%$ while peel thickness decreased by $29-75 \%$. An increase of $39 \%$ juice weight per fruit was obtained in $150 \mathrm{~g} \mathrm{~K}$. The yield of juice per tree increased up to 11 times with $225 \mathrm{~g} \mathrm{~K}$ level. The $225 \mathrm{~g} \mathrm{~K}$ rates also increased juice $\mathrm{pH}$ by $8-12 \%$, titrable acidity and total soluble solids per tree by 9 times and 6 times, respectively. The application of $225 \mathrm{~g} \mathrm{~K}$ basal + foliar resulted to higher fruit weight, TA, and TSS in pummelo fruit. The results of the study showed the important role of $\mathrm{K}$ in improving the fruit quality of 'Magallanes' pummelo.

\section{ACKNOWLEDGMENT}

This work was supported in part by grants from the PCAARRD (Philippine Council for Agriculture, Aquatic and Natural Resources Research and Development), DOST-SEI (Department of Science and Technology-Science Education Institute) and SODACO (South Davao Corporation). 


\section{REFERENCES}

Alva AK, Paramasivam S, Patil B, De Mattos D Jr., Dou H \& Sajwan K. 2002. Role of potassium on sustainable citrus production. www.ipipotash.org/udocs/ potassiumcitrusproduction.pdf

Association of Official Analytical Chemists (AOAC) International. 2005. Official methods of analysis (18th edn)

Benavente-Garcia O, Castillo J, Marin FR, Orturo A \& Del Rio JA. 1997. Uses and properties of citrus flavonoids. Journal of Agricultural and Food Chemistry 45(12):4505-4515

Calvert DV. 1973. Response of 'Marsh' grapefruit trees in the Indian river area to potassium application and fruit quality. Proceedings from the Florida State Horticulture Society 86:13-19

Choureitah A and Bünemann G. 1972. The effect of K-supply on chemical composition of Fragaria vesca var. Semperflorens Duch. Gartenbauwissenschaft 37:243-249

Embleton TW and Jones WW. 1964. Potassium and lemon fruit quality. California Citrology 51:269. In Alva AK, Paramasivam S, Patil B, De Mattos D Jr. , Dou H \& Sajwan K (eds) Role of potassium on sustainable citrus production. www.ipipotash.org/udocs/potassiumcitrusproduction.pdf

Erner Y, Artzi B, Tagari E \& Hamou M. 2005. Potassium affects citrus tree performance. The Volcani Center, Institute of Horticulture, Department of Fruit Trees

Estellena NT and Odtojan RC. 1992. Pomological characterization of eight pummelo cultivars, Citrus maxima (Burm.) Merr. Davao National Crop Research and Development Center, Department of Agriculture, Region XI

Fageria NK and Gheyi HR. 1999. Efficient crop production. Campina Grande, Universidade de Paraíba

Guardiola JL. 1997. Overview of flower bud induction, flowering and fruit set in citrus. Universidad Politecnica de Valencia, Valencia, Spain

Guthrie N, Morley K, Hasegawa S, Manners GD \& Vandernberg T. 2000. Inhibition of human breast cancer cells by citrus limonoids. ACS Symposium Series 758:164-174

Hale CR. 1977. Relation between potassium and the malate and tartrate contents of grape berries. Vitis 16(1):9-19

Hobson GE and Davis JN. 1971. The tomato. In Hulme AC (ed) The biochemistry of fruits and their products 2:437-482. Academic Press

Koo RCJ. 1963. Nitrogen and potassium rates study on lemon. Florida University of Agriculture Experiment Station Annual Report. In Alva AK, Paramasivam S, Patil B, De Mattos D Jr., Dou H \& Sajwan K (eds) Role of potassium on sustainable citrus production. www.ipipotash.org/udocs/potassiumcitrusproduction.pdf

Kumar N, Meenakshi N, Suresh J \& Nosov V. 2006. Effect of potassium nutrition on growth, yield and quality of papaya (Carica papaya L.). Indian Journal of Fertilizers 2(4):43-47

Lis-Balchin M and Hart S. 1999. Studies on the mode of action of the essential oil of lavender (Lavandula angustifolia P. Miller). Phytotherapy Research 13(6):540542

Magat SS and Mantiquilla JA. 2005. Crop nutrition and fertilization management of selected tropical fruit crops. PCARRD Los Baños, Laguna

Middleton E and Kandaswami C. 1994. Potential health promoting properties of citrus flavonoids. Food Technology 48(11):115-11 
Mimoun M, Ben M, Ghrab M, Ghanem M \& Elloum O. 2009. Effects of potassium foliar spray on olive, peach and plum. Part 2: Peach and Plum Experiments, e-ifc No. 19-Research Findings

Njoroge SM, Koaze H, Karanja PN \& Sawamura M. 2005. Volatile constituents of redblush grapefruit (Citrus paradisi) and pummelo (Citrus grandis) peel essential oils from Kenya. Journal of Agricultural and Food Chemistry 53(25):9790-9794

Perkins-Veazie P and Roberts W. 2002. Can potassium application affect the mineral and antioxidant content of horticultural crops? Proceedings of the Symposium on Fertilizing Crops for Functional Food

Philippine Statistic Authority (PSA). 2014. Commodity Fact Sheet, https://psa.gov.p h/sites/default/files/commodity_factsheet2013.pdf

Reese RL and Koo RCJ. 1974. Responses of 'Hamlin,' 'Pineapple,' and 'Valencia' orange trees to nitrogen and potash applications. Proceedings from the Florida State Horticulture Society 87:1-5

Reese RL and Koo RCJ. 1975. Effects of N and K fertilization on internal and external fruit quality of three major Florida orange cultivars. Journal of American Society of Horticulture Science 100:425-428

Reische DW, Lillard DA \& Eitenmiller RR. 1998. In Ahoh CC and Min DB (eds) Chemistry, nutrition and biotechnology (pp423-448). Marcel Dekker, New York

Sites JW and Deszyck EJ. 1952. The effect of varying amounts of K on the yield and quality of Valencia and Hamlin oranges. In Alva AK, Paramasivam S, Patil B, De Mattos D Jr., Dou H \& Sajwan K (eds) Role of potassium on sustainable citrus production. www.ipipotash.org/udocs/potassiumcitrusproduction.pdf Proceedings from the Florida State Horticulture Society 68:65-72

Smith SN. 2009. What is a pummelo. Wisegeek article. http://www.wisegeek.com /what-is-a-pummelo.htm

The National RDE Network For Fruit Crops. 2002. Fruits: the national research, development and extension agenda and program for fruit crops. BAR, Quezon City

Tsai HL, Chang SKC \& Chang SJ. 2007. Antioxidant content and free radical scavenging ability of fresh red pummelo [Citrus grandis (L.) Osbeck] juice and freeze-dried products. Journal of Agricultural Food Chemistry 55(8):2867-2872

Van Bel AJE and Van Erven AJ. 1979. A model for proton and potassium cotransport during the uptake of glutamine and sucrose by tomato internode disks. Planta 145:77-82 